\title{
ANALISIS POSISI BERSAING PERUSAHAAN BATIK MENGGUNAKAN THE INDUSTRY ATTRACTIVENES BUSINESS STRENGTH MATRIX (MDTI)STUDY KASUS DI TOBAL BATIK
}

\author{
Yustiana Dwirainaningsih", Indah Kuswardani \\ Politeknik Pusmanu Pekalongan
}

Korespondensi: dwirainaningsih@gmail.com

\begin{abstract}
Tobal Batik is a home industry that is engaged in the production and sale of batik cloth and batik clothing that is located at Jalan Terai No. 24 Pekalongan The number of other home industries which are engaged in selling batik has quite prospective business opportunities. The increasingly tight competition among batik sellers requires Tobal Batik management to be able to anticipate the emergence of threats from competitors and be able to take advantage of the opportunities and strengths the company has. To achieve this goal, Tobal Batik needs to pay attention to two main factors in the company, namely external and internal factors. External factors are factors that are not influenced by company policy, while internal factors can be influenced by company policy to optimize sales volume that is entirely within the control of the company. To analyze these external and internal factors, a purposive samplin can be used whose purpose is to determine the position of Tobal Batik in the market based on the strengths, weaknesses, opportunities and threats that the company has. Whereas in analyzing business opportunities and the extent to which products produced by Tobal Batik are able to compete in the market, it will be analyzed using the MDTI matrix which serves to see the marketing position of Tobal Batik based on market growth and market share. In order to create a competitive space, companies need to make plans in marketing strategies, so that product sales can increase in the market and provide benefits for the company.
\end{abstract}

Keywords: Marketing strategy, Competitive position, MDTI

\section{PENDAHULUAN}

Tetapi tanpa disadari oleh kita bahwa kebutuhan akan sandang yang terus meningkat dari tahun ke tahun untuk memenuhi pangsa pasar salah satunya adalah batik, batik merupakan salah satu hasil karya budaya bangsa Indonesia yang berkembang secara turun temurun dan telah mendapat pengakuan secara Internasional. Di Indonesia batik merupakan hasil produksi yang menjadi komoditas perdagangan antar daerah dan juga sebagai komoditas ekspor andalan Indonesia. Dengan adanya variasi motif batik yang berasal dari modifikasi motif modern yang dipadukan dengan motif tradisional, telah mempercepat pemasyarakatan batik di kalangan umum. Batik kini telah menjadi komoditi industri yang bersifatmasal. Karena semakin banyak perusahaan batik yang tersebar di Indonesia, maka persaingan dalam menjalankan usaha tidak dapat dihindari lagi. Maka untuk mempertahankan kelangsungan hidup perusahaan, khususnya dalam menjalankan kegiatan usaha untuk memperoleh profit Tobal Batik berusaha meningkatkan dan mengatur strategi dalam rangka meningkatkan penjualan produknya. Seperti yang diungkapkan oleh (R.A Supriyono : 2000 : 9) Strategi adalah salah satu kesatuan rencana yang komprehensif dan terpadu dengan menghubungkan kekuatan strategi perusahaan dengan lingkungan yang dihadapi, kesemuanya menjamin agar tujuan perusahaan tercapai. Dalam menentukan strategi bagi perusahaan perlu mengetahui secara menyeluruh yaitu posisi bisnis dalam hal ini adalah kekuatan dan kelemahan. Pokok perumusan strategi bersaing adalah mengkhususkan perusahaan dengan bisnisnya. Kemungkinan akan ada hambatan yang 
akan dihadapi baik dari faktor intern perusahan dan pesaing pasar, maupun konsumen, sehingga dapat mengantisipasinya lebih dini.

Analisis strategi bersaing menunjukkan perbedaan dan keunikan di antara pesaing, sumber keunggulan bersaing adalah ketrampilan, sumber daya dan pengendalian yang superior. Ketrampilan yang superior akan memungkinkan organisasi untuk memilih dan melaksanakn strategi yang akan membedakan organisasi dari pesaing. Dengan adanya pesaingan maka produsen sadar akan pentingnya kegiatan bersaing sebagai penentu keberhasilan perusahaan untuk masa yang akan datang terhadap perusahaan pesaingnya, tujuannya untuk menaikkan atau mempertahankan volume penjualan. Seperti yang diungkapkan oleh (Michael E. Porter : 2000 : 5) ada 5 (lima) kekuatan baik sifat dan derajat persaingan dalam suatu industri di antaranya, masuknya pendatang baru,ancaman produk pengganti,kekuatan tawar menawar pembeli, kekuatan tawar menawar pemasok, pesaingan di antara para pesaing yang ada.

\section{LANDASAN TEORI}

\subsection{Matrik Daya Tarik Industri (MDTI) Pengertian MDTI}

Penentu dasar pertama dari kemampuan laba suatu perusahaan adalah daya tarik industri. Untuk itu maka penyusunan Matriks Daya Tarik Industri (MDTI) dapat menggambarkan posisi perusahaan terhadap lingkungan industri dan persaingan antar perusahaan baik sekarang maupun masa yang akan datang.

Pendekatan MDTI, semula dibuat untuk membantu manajemen menganbil keputusan investasi pada berbagai portofolio bisnis yang dikeloala, yang biasanya berada pada perusahaan besar yang terdiversikasi, yaitu dengan cara terlebih dahulu melakukan dekomposisi perusahaan menjadi unit usaha strategis (U2S).

Ada dua sumbu matrik dalam MDTI yaitu vertikal dan horisontal, sumbu vertikal digambarkan untuk menggambarkan kekuatan perusahaan (business strengths) yang sebelumnya telah diukur dan dihitung berdasarkan indikator yang telah disepakati bersama sesuai dengan pendekatan yang dipilih oleh manajmen. Sedangkan sumbu horizontal menggambarkan tentang ancaman peluang bisnis yang beasal dari beberapa indikator yang ada di dalam .

Penelitian terdahulu yang memiliki kemiripan baik dalam segi objek penelitian, metode ataupun pendekatan yang digunakan agar dapat dijadikan pembeda dengan penelitian yang dilakukan saat ini. Adapun beberapa penelitian yang ditemukan dan memiliki relevansi dengan permasalahan yang dikembangkan dalam penelitian ini antara lain :

Sari, et.al (2003) melakukan analisa strategi keunggulan bersaing perusahaan di PT. ILUFA (Inti Luhur Fuja Abadi) Desa Cangkringmalang Kecamatan Beji Kabupaten Pasuruan Jawa Timur. Tujuan dari penelitian tersebut adalah untuk (1) mengidentifikasi sumber daya yang ada di perusahaan, (2) menganalisa faktor-faktor lingkungan eksternal dan internal perusahaan, (3) menganalisa kekuatan, kelemahan, peluang dan ancaman perusahaan sehingga dapat dirumuskan strategi keunggulan bersaing yang dimiliki perusahaan.

Metode yang digunakan metode penelitian deskriptif dengan menganalisis elemen-elemen yang mendukung strategi keunggulan bersaing keunggulan bersaing PT ILUFA. Hasil penelitian menunjukkan bahwa lingkungan perusahaan mempengaruhi kegiatan perusahaan.hasil analisis faktor eksternal diperoleh nilai 2,72; hasil analisis faktor internal diperoleh nilai 2,67; hasil analisis SWOT perusahaan berada pada sel 1; dari matriks GE berada pada sel V. Maka disimpulkan bahwa berdasarkan hasil analisis ETOP, SAP, SWOT dan GEM pada PT ILUFA, perusahaan 
berada dalam kondisi rata-rata. berdasarkan analisis QSPM diperoleh strategi yang paling tepat diterapkan oleh perusahaan adalah strategi Market Development.

Puspitasari, et.al. (2013) melakukan pemilihan strategi bisnis pada sentra industri gerabah kasongan, Bantul, DIY. Peneliti melakukan analisis lingkungan eksternal dan internal yang dijadikan acuan utama untuk melakukan perbaikan strategi pemasaran. Penetapan prioritas strategi diperoleh dari hasil analisis SWOT dengan matriks QSPM (Quantitative Strategic Planning Matrix). Model MAUT (Multi Attribute Utility Theory) juga digunakan untuk membandingkan prioritas strategi bisnis dengan melihat segi infrastruktur, waktu, cost dan pendapat pengusaha dalam penelitian ini.

Dari hasil penelitian, dapat diperoleh strategi yang paling tepat digunakan oleh IKM gerabah yaitu melakukan strategi pengembangan produk dan penetrasi pasar. Selain itu membuat Desa Kasongan lebih menarik dengan mengembangkan desa menjadi daerah wisata yang memang menarik untuk dikunjungi.

\subsection{Strategi}

\subsubsection{Definisi Strategi}

Pada dasarnya strategi merupakan sarana yang digunakan untuk mencapai tujuan akhir atau sasaran. Menurut Agyris, Mintzberg, Steiner, dan Miner"Strategi merupakan respon secara terus-menerus maupun adaptif terhadap peluang dan ancaman eksternal serta kekuatan dan kelemahan internal yang dapat mempengaruhi organisasi” (R.A. Supriyono, 2000 :10).

a) Glueck

"Strategi adalah rencana yang disatukan, menyeluruh, terpadu yang mengaitkan keunggulan strategi perusahaan dengan tantangan lingkungan dan yang dirancang untuk memastikan bahwa tujuan utama perusahaan dapat dicapai melalui pelaksanaan yang tepat oleh perusahaan." (Fandy Tjiptono, 2008: 3)

b) Andrew dan Chaffe,

"Strategi adalah kekuatan motivasi untuk stakeholders, seperti manajer, karyawan, konsumen, komunitas, pemerintah, dan sebagainya, yang baik secara langsung maupun tidak langsung menerima keuntungan atau biaya yang ditimbulkan oleh semua tindakan yang dilakukan oleh perusahaan.” (R.A. Supriyono, $2000: 11$ )

Berdasarkan beberapa pendapat di atas, dapat disimpulkan bahwa pengertian strategi adalah rencanayang disusun oleh suatu perusahaan atau organisasi untuk mencapai tujuan dari perusahaan atau organisasi tersebut.

2.4.2. Manfaat Strategi Perusahaan SecaraUmum

Adapun manfaat strategi bagi perusahaan secara umum adalah:

a) Sebagai cara untuk mengantisipasi masalah-masalah perusahaan di masa depan pada kondisi perusahaan yang berubah secaracepat.

b) Dapat memberikan tujuan dan arah perusahaan di masa depan dengan jelas kepada semuakaryawan.

c) Membuat tugas para eksekutif puncak menjadi lebih mudah dan kurangberesiko.

Untuk memonitor apa yang dikerjakan dan apa yang terjadi di dalam perusahaan agar dapat memberikan sumbangan terhadap kesuksesan perusahaan atau justru mengarah padakegagalan. 


\subsection{Konsep Pemasaran}

Konsep pemasaran merupakan filsafat bisnis, karena kegiatan pemasaran merupakan faktor penting untuk mencapai suskses bagi setiap perusahaan. Konsep pemasaran berpendapat bahwa kunci untuk mencapai tujuan organisasi terdiri dari penetuan kebutuhan dan keinginan pasar sasaran serta penyerahan produk yang memuaskan secara lebih efektif danlebih efisien dari para pesaing (Philip Kolter : 1996 :30 ). Sedangkan definisi dari konsep pemasaran adalah sebuah falsafah bisnis yang menyatakan bahwa pemuas kebutuhan konsumen merupakan syarat ekonomi dan sosial dengan kelangsungan hidup ( Basu Swasta dan Irawan 2000: 5 )

\subsection{Pengertian Manajemen Strategik}

Manajemen strategik adalah usaha manajerial menumbuhkembangkan kekuatan perusahaanuntuk mengeksploitasi peluang bisnis yang muncul guna mencapai tujuan perusahaan yang telah ditetapkan sesuai dengan misi yang telah ditentukan (Suwarsono 2013 : 6). Pengertian ini juga mengandung implikasi bahwa perusahaan berusaha mengurangi kelemahannya dan melakukan adaptasi dengan lingkungan bisnisnya di samping itu perusahaan berusaha untuk mengurangi efek negatif yang ditimbulkan oleh ancaman bisnis (Sri Wayudi 2013 : 15) berpendapat bahwa manajemen strategi dapat diartikan sebagai suatu ilmu dari pembuatan (formulating), penerapan (implementing) dan evaluating.Pada dasarnya dari definisi di atas bahwa manajmen strategik ada dua yaitu :

2.4.1. Proses Manajemen Strategik ada 3 ( Tiga )

a) Pembuatan strategi

Meliputi pengembngan misi dan tujuan jangka panjang, pengidentifikasian peluang dan ancaman dari luar serta kekuatan dan kelemahan perusahaan, pengembangan alternatif-alternatif strategi dan penentuan strategi yang sesuai

b) Penerapan strategi

Meliputi penetuan sasaran-saran dan mengakolasikan sumbersumber daya agar strategi yang diterapkan dapat diimplementasikan

c) Evaluasi strategi

Mengukur konerja individu termasuk di dalamnya hasil-hasil pembuatan dan penerapan strategi.

\subsubsection{Fokus Manajemen Strategik}

Memfokuskan pada penggabungan aspek-aspek pemasaran, riset dan pengembangan, keuangan dan produksi dari sebuah bisnis.

\section{METODE PENELITIAN}

Penarikan sampel dalam penulisan ini menggunakan metode purposive sampling, dimana pertimbangan yang digunakan berdasarkan pada teoritis. Oleh karena itu dalam mencari informasi didasarkan pada orang-orang yang dianggap tepat yaitu mereka yang mengetahui dan mengerti latar belakang mengenai pemasaran untuk dijadikan data disampling itu untuk menganalisa data yang diperoleh menggunakan analisis Matrik Daya Tarik Industri (MDTI), MDTI baru dapat disusun setelah manajemen mampu mengidentifikasi dan memberikan penilaian pada variabel internal dan variabel eksternal yang berpengaruh secara signifikan terhadap peluang bisnis yang muncul dan kekuatan perusahaan yang dimiliki. Pada dasarnya tidak ada perbedaan yang berarti antara prosedur 
penyusunan MDTI untuk dimensi waktu yang sekarang dan waktu yang akan datang, keduanya berusaha menemukan dan memberikan penilaian terhadap variabel eksternal dan internal. Jika pada masa sekarang diperlukan identifikasi, pada masa yang akan datang diperlukan prediksi.

Penelitian ini akan membahas mengenai analisis posisi bersaing perusahaan batik . Adapun yang menjadi objek dalam penelitian ini adalah strategi bisnis yang dihasilkan dari analisis faktor-faktor internal perusahaan (strengths dan weaknesses) dan faktor-faktor eksternal perusahaan(opportunities dan threats). Sedangkan yang menjadi subjek dalam penelitian ini adalah Tobal Batik di Jalan Teratai no. 24 Kota Pekalongan

Tabel 1 Prosedur Penyusunan MDTI

\begin{tabular}{|c|c|}
\hline Posisi Sekarang & Posisi Masa Depan \\
\hline $\begin{array}{l}\text { 1. Identifikasi variabel eksternal dan internal } \\
\text { yang signifikan }\end{array}$ & $\begin{array}{l}\text { 1. Prediksi variabel internal dan eksternal (jika ada } \\
\text { perbedaan) }\end{array}$ \\
\hline 2. Penilaian Variabel eksternal & 2. Prakiraan kecenderungan variabel eksternal \\
\hline 3. Penilaian variabel internal & 3. Prakiraan nilai variabel internal \\
\hline 4. Penentuan posisi bisnis & $\begin{array}{l}\text { 4. Prakiraan Posisi Bisnis } \\
\text { 5. Perumusan Strategis }\end{array}$ \\
\hline
\end{tabular}

Sumber : Manajemen,konsep, alat analisas dan konteks, ( Suwarsono, hal 133)

MDTI memiliki sembilan sel yang terbentuk setelah masing-masing sumbu dibagi tiga bagian dengan titik pembagi masing-masing bagian adalah : bagian rendah, bagian tengah (medium) dan bagian tinggi, secara sederhana MDTI dapat dilihat sebagai berikut :

Tabel 2 Matrik Daya Tarik Industri

\begin{tabular}{|c|c|c|c|c|}
\hline & & \multicolumn{3}{|c|}{ Daya Tarik Industri } \\
\hline & & Tinggi & Medium & Rendah \\
\hline \multirow{3}{*}{ Kekuatan Bisnis } & Tinggi & Investasi dan tumbuh & Pertumbuhan selektif & selektif \\
\hline & Medium & Pertumbuhan selektif & selektif & Panen / Divestasi \\
\hline & Rendah & Selektif & Panen / Divestasi & Panen / Divestasi \\
\hline
\end{tabular}

Sumber : Manajemen,konsep, alat analisas dan konteks, ( Suwarsono , hal 133)

Cara mencari posisi perusahaan pada Matrik Daya Tarik Industri :

1) Mengevaluasi variabel eksternal dan variabel internal

Indikator variabel eksternal dan variabel internal memiliki hubungan pengaruh terhadap perusahaan, kemudian diberi penilaian terhadap masing-masing indikator. Dengan penilaian tersebut diharapkan dapat diketahui berapa besar sumbangan yang diberikan masing-masing indikator terhadap perusahaan. Untuk nilai digunakan berskala lima, yaterhadap perusahaan. itu

$\begin{array}{ll} & \text { Score } \\ \text { 1. Sangat tidakbaik } & 1 \\ \text { 2. Tidak baik } & 2 \\ \text { 3. Netral } & 3 \\ \text { 4. Baik } & 4 \\ \text { 5. Sangat Baik } & 5\end{array}$

2) Pemberian bobot kepentingan pada variabel eksternal dan internal

Sebelum penilaian dilakukan, masing-masing indikator ditentukan terlebih dahulu bobotnya. Pemberian bobot sesuai besar kecilnya pengaruh. Total bobot dari variabel terebut adalah 1 atau $100 \%$. 
Kemudian untukmencari ranting nilai variabel eksternal dan internal dengan cara mengalikan nilai evaluasi dengan bobot kepentingan. Hasildari perhitungan ini memiliki nilai maksimal 5 dan nilai terendah adalah nol, yang mempunyai rentang sebagai berikut: perusahaan dengan ancaman besar tanpa peluang sedikitpun, perusahaan dengan peluang dan ancaman sama besar, perusahaan tanpa atau dengan ancaman kecil dan peluang besar (Suwarsono $2013: 138$ ).

\section{HASIL DAN PEMBAHASAN}

Setelah melakukan interview terhadap pihak manajemen dihasilkan identifikasi indikator variabel internal dan eksternal terlihat dalam tabel berikut

\subsection{Penilaian Variabel Internal}

Tabel 3 Indikator variabel Internal dan Eksternal

\begin{tabular}{|c|c|}
\hline Indikator Variabel Internal & Indikator Variabel Eksternal \\
\hline 1. Citra Produk & 1. Pertumbuhan pasar \\
\hline 2. Variasi Produk & 2. Perkembangan teknologi \\
\hline 3. Lokasi perusahaan & 3. Struktur pesaingan \\
\hline 4. Kualitas produk & 4. Perubahan selera konsumen \\
\hline 5. Kualitas karyawan & 5. Pesaing baru yang masuk \\
\hline 6. Efektivitas saluran distribusi & 6. Depresiasi mata uang \\
\hline 7. Kebijakan harga & 7. Daya beli konsumen \\
\hline 8. Pangsa pasar & 8. Aturan pemerintah \\
\hline 9. Efisiensi biaya produksi & 9. Hambatan memasuki pasar \\
\hline
\end{tabular}

Tabel 4 Penilaian Variabel Internal

\begin{tabular}{lcc}
\hline \multicolumn{1}{c}{ Indikator Variabel Internal } & Nilai & Keterangan \\
\hline 1. Citra Produk & 4.2 & Baik \\
2. Variasi Produk & 3.6 & Netral \\
3. Lokasi perusahaan & 4.6 & Baik \\
4. Kualitas produk & 3.8 & Netral \\
5. Kualitas karyawan & 2.4 & Tidak Baik \\
6. Efektivitas saluran distribusi & 2.8 & Tidak Baik \\
7. Kebijakan harga & 2.6 & Tidak Baik \\
8. Pangsa pasar & 4.4 & Baik \\
9. Efisiensi biaya produksi & 3.4 & Netral
\end{tabular}

\begin{tabular}{lccc}
\hline \multicolumn{4}{c}{ Tabel 5 Evaluasi Faktor Internal (IFE Matrik) } \\
\hline \multicolumn{1}{c}{ Faktor Internal } & Bobot & Nilai & Nilai Tertimbang \\
\hline 1. Citra Produk & 0.12 & 4.2 & 0.50 \\
2. Variasi Produk & 0.13 & 3.6 & 0.46 \\
3. Lokasi perusahaan & 0.10 & 4.6 & 0.46 \\
4. Kualitas produk & 0.12 & 3.8 & 0.45 \\
5. Kualitas karyawan & 0.13 & 2.4 & 0.31 \\
6. Efektivitas saluran distribusi & 0.11 & 2.8 & 0.30 \\
7. Kebijakan harga & 0.11 & 2.6 & 0.28 \\
8. Pangsa pasar & 0.10 & 4.4 & 0.44 \\
9. Efisiensi biaya produksi & 0.11 & 3.4 & 0.137 \\
\hline
\end{tabular}

Dalam kasus ini Tobal Batik digunakan kriteria yang dipakai oleh manajemen yang kurang berani menanggung resiko (risk averse),maka dengan nilai pertimbangan sebesar 3,57 termasuk katagori Medium, dengan kata lain bahwa Tobal Batik memiliki peluang bisnis yang cukup. Secara relatif ancaman masih lebih rendah dibandingkan dengan peluang untuk berkembang.

1) Citra Produk

Bahwa sampai sekarangpun produk jadi batik di Tobal Batik masih diminati oleh konsumen karena memiliki produk yang bagus dan diminati oleh 
konsumen dari dan luar dan dalam negeri oleh sebab itu maka nilai di perusahaan sebesar 4,2 dengan bobot nilai 0.12

2) Variasi Produk

Dengan ada variasi ukuran produk dan jenisnya hal ini sangat membantu konsumen dalam hal ini maka perusahaan memberikan nilai 3,5 dan bobot nilai sebesar 0.13

3) Lokasi perusahaan

Karena lokasinya yang strategis maka akan mendukung kinerja perusahaan karena secara tidak langsung akan memperoleh dampak positif dalam memasarkannya untuk itu perusahaan memberikan nilai 4,6 dan bobot nilai sebesar 0.10

4) Kualitas produki

Tobal Batik selalu mengutamakan kualitas dari mulai bahan baku sampai dengan bahan jadi, karena dengan adanya produk batik yang berkualitas akan dapat menambah kepercayaan konsumen untuk itu perusahaan memberikan nilai 3,8 dan bobot nilai sebesar 0,12

5) Kualitas karyawan

SDM merupakan faktor vital dalam sebuah perusahaan tanpa kecuali, karena itu perusahaan penting memberikan respon yang tinggi terhadap variabel ini, Tobal Batikdalam masalah SDM kali ini sangatlah minim karena dulunya merupakan perusahaan home industry karena dalam perekrutan sangatlah susah dan di Tobal Batik kebanyakan karyawannya adalah orang-orang yang telah menguasai bidangnya oleh sebab ituperusahaan memberikan nilai 2.4 dengan bobot nilai sebesar 0,13 .

6) Efektivitas saluran distribusi

Di Tobal Batik merupakan salah satu perusahaan eksport, maka untuk masalah pendistribusian produk batik tergantung dari order untuk itu perusahaan memberikan nilai 2.8 dengan bobot 0.11 .

7) Kebijakan harga

Kebijakan harga yang ditetapkan oleh perusahaan akan menjadi perhatian khusus hal ini juga berlaku di Tobal Batik di sini Tobal Batik mampu menciptakan keunggulan lain seperti pada biaya produksi yang pada gilirannya akan berpengaruh terhadap kebijakan harga sebab itu nilai yang ada dengan 2.6 dan bobot nilai sebesar 0.11 .

8) Pangsa pasar

Pangsa pasar yang dimiliki perusahaan adalah sangat penting dalam upaya memenangkan persaingan, karrena dari sisi pangsa pasar ini pulalah dapat dikenali posisi perusahaan. Golongan pelanggan pada Tobal Batik adalah pada tingkat menengah keatas oleh sebab itu nilai yang diberikan 4.4 dan bobotnya 0.10 .

9) Efisiensi biaya produksi

Pada faktor efisiensi biaya produksi Tobal Batik lebih mengutamakan pelanggan jadi untuk menekan masalah harga keseluruhan berdasarkan pada kesepakatan antara kedua belah pihak, untuk itu nilai yang diberikan 3.4 dengan bobot nilai 0.11 . 


\subsection{Penilaian Variabel Eksternal}

Tabel 6 Penilaian Variabel Eksternal

\begin{tabular}{llcc}
\hline & Indikator Variabel Internal & Nilai & Keterangan \\
\hline 1. & Pertumbuhan pasar & 3 & Netral \\
2. Perkembangan teknologi & 3.6 & Baik \\
3. Struktur pesaingan & 2.8 & Tidak Baik \\
4. Perubahan selera konsumen & 4 & Baik \\
5. Pesaing baru yang masuk & 3.2 & Netral \\
6. Depresiasi mata uang & 3 & Netral \\
7. Daya beli konsumen & 4.4 & Baik \\
8. Aturan pemerintah & 3.2 & Netral \\
9. & Hambatan memasuki pasar & 2.6 & Tidak Baik \\
\hline
\end{tabular}

Tabel 7 Evaluasi Faktor Internal ( EFE Matrik )

\begin{tabular}{llcc}
\hline \multicolumn{1}{c}{ Faktor Internal } & Bobot & Nilai & Nilai Tertimbang \\
\hline 1. Pertumbuhan pasar & 0.11 & 3 & 0.33 \\
2. Perkembangan teknologi & 0.11 & 3.6 & 0.39 \\
3. Struktur pesaingan & 0.12 & 2.8 & 0.33 \\
4. Perubahan selera konsumen & 0.12 & 4 & 0.48 \\
5. Pesaing baru yang masuk & 0.12 & 3.2 & 0.38 \\
6. Depresiasi mata uang & 0.10 & 3 & 0.30 \\
7. Daya beli konsumen & 0.12 & 4.4 & 0.52 \\
8. Aturan pemerintah & 0.09 & 3.2 & 0.28 \\
9. Hambatan memasuki pasar & 0.10 & 2.6 & 0.26 \\
\hline
\end{tabular}

Dengan menggunakan tafsir konsertatif, karena manajemen termasuk dalam katagori kurang berani menanggung resiko ( risk averse) dengan angka pertimbangan sebesar 3.28 dapat digolongkan pada golongan medium dari sumbu horisontal matrik oleh karenanya Tobal Batik memiliki keunggulan yang menarik.

1) Pertumbuhan pasar

Peningkatan pertumbuhan pasar yang terus meningkat dan banyaknya perusahaan batik yang sejenis mengakibatkan persaingan semakin ketat antara perusahaan batik hal ini yang mengakibatkan Tobal Batik lebih waspada terhadap kondisi yang ada oleh sebabnya penilainnya diberikan 3 dengan bobot nilai sebesar 0.11 .

2) Perkembangan teknologi

Perkembangan teknologi belakangan ini semakin pesat, tetapi pada Tobal Batik tidak begitu mencolok dikarenakan perusahaan ini merupakan perusahaan tradisional yang semunya dikerjakan oleh tangan trampil dan berpengalaman serta harus rapi. Untuk itu nilai yang diberikan adalah 3 dengan bobot sebesar 0.11 .

3) Struktur pesaingan

Struktur persaingan produk batik di Kota Pekalongan sangat kompetitif. Dikatakan sangat kompetitif karena banyaknya perusahaan-perusahaan yang sama-sama bergerak pada produk batik. Tetapi setiap perusahaan mempunyai ciri khas masing-masing dan mempunyai pelanggan yang sudah tetap,oleh sebab itu perusahaan memrikan nilai 2.8 dengan bobot sebesar 0.12 .

4) Perubahan selera konsumen

Tobal Batik sangat memperhatikan selera-selera para konsumen oleh sebab itu konsumen yang ada di Tobal Batik rata-rata dapat menentukan sendiri produk batik dari mulai desain,warna dan motif . nilai yang diberikan sebesar 4 dengan bobot sebesar 0.12 . 
5) Pesaing baru yang masuk

Perusahaan harus cermat mengamati gerak gerik pesaing baru yang memasuki pasar dengan persaingan yang konpetitif. Di sini Tobal Batik harus melakukan 2 (dua) hal yaitu menjaga keunggulan dengan produk pakaian jadi yang banyak diminati konsumen dan melakukan juga upaya-upaya diferensi terutama pada elemen produk batik itu sendiri yang selama ini sangat kurang diminati oleh konsumen, nilai yang diberikan sebesar 3.2 dengan bobot sebesar 0.12 .

6) Depresiasi mata uang

Depresiasi rupiah terhadap dollar AS saat ini akan berpengaruh besar atau menjadi salah satu ancaman bagi kelanjutan produk perusahaan tetapi hal ini tidak menjadi soal bagi Tobal Batik apabila ada kenaikan nilai mata uang tetapi apabila ada penurunan nilai mata uang dan menjadi persoalan sangat besar, nilai yang diberikan sebesar 3 dengan bobot sebesar 0.10 .

7) Daya beli konsumen

Variabel ini memang cukup penting, hal ini didasarkan pada membaiknya pasar produk batik meskipun hal tersebut juga dibarengi oleh tingkat persaingan perusahaan yang cukup tajam, hal ini ditandai dengan meningkatnya permintaan konsumen terhadap produk batik baik untuk eksport ataupun lokal, nilai yang diberikan sebesar 4.4 dengan bobot sebesar 0.12.

8) Aturan pemerintah

Dengan adanya peraturan dari pemerintah maka setidaknya Tobal Batik harus mengikuti aturan tersebut asalkan sesuai dengan kondisi perusahaan, nilai yang diberikan sebesar 3.2 dengan bobot sebesar 0.09

9) Hambatan memasuki pasar

Hambatan memasuki pasar bagi tobalbatik pasti tetap ada, tetapi asalkan perusahaan dapat bersaing dengan perusahaan lain oleh sebab itu Tobal Batik melakukan komunikasi terhadap buyer-buyer melalui pameran baik yang diselenggarakan oleh pemrintah atau swasta, nilai yang diberikan sebesar 2.6 dengan bobot sebesar 0.10

\subsection{Penentuan Posisi Bisnis}

Berdasarkan pada nilai hasil pertimbangan ke dua variabel maka bisa dikatakan Tobal Batikberada pada sel pertumbuhan selektif. Artinya bahwa perusahaan memiliki peluang bisnis cukup prospektif untuk berkembang lebih lanjut sebagai perusahaan yang meningkatkan terhadap kekuatan ataupun keunggulan-keunggulan yang dimiliki. Berdasarkan posisi tersebut dapat dilihat detail implikasi strategis.

Tabel 8 Detail Implikasi Strategis

\begin{tabular}{|c|c|c|c|c|}
\hline & & \multicolumn{3}{|c|}{ Daya Tarik Industri } \\
\hline & & Tinggi & Medium & Rendah \\
\hline \multirow{3}{*}{$\begin{array}{l}\text { Kekuatan } \\
\text { Bisnis }\end{array}$} & Tinggi & $\begin{array}{l}\text { Pertumbuhan dominasi investasi } \\
\text { maksimum }\end{array}$ & $\begin{array}{l}\text { Pertumbuhan selektif investasi agresif, } \\
\text { memelihara posisi di tempat lain }\end{array}$ & $\begin{array}{l}\text { memelihara posisi, mencari sumber } \\
\text { kas masuk, investasi ala kadarnya }\end{array}$ \\
\hline & Medium & $\begin{array}{l}\text { Memimpoin pasar berdasarkan } \\
\text { segmen, memperbaiki kelemahan } \\
\text { membangun keunggulan }\end{array}$ & $\begin{array}{l}\text { Tumbuh berdasarkan segmen pasar, } \\
\text { spesialisasi investasi selektif }\end{array}$ & $\begin{array}{l}\text { Pemangkasan investasi, minimal } \\
\text { bersiap divestasi }\end{array}$ \\
\hline & Rendah & $\begin{array}{l}\text { Spesialisasi mencari ceruk pasar } \\
\text { mempertimbangkan akuisisi }\end{array}$ & $\begin{array}{l}\text { Spesialisasi mencari ceruk pasar, } \\
\text { mempertimbangkan keluar dari pasar }\end{array}$ & $\begin{array}{l}\text { Mengikuti pemimpin pasar, } \\
\text { mengacaukan sumber aliran kas } \\
\text { pesaing divestasi }\end{array}$ \\
\hline
\end{tabular}




\section{KESIMPULAN DAN SARAN}

\subsection{Simpulan}

1) Pada variabel internal Tobal Batik digunakan kriteria yang dipakai oleh manajemen yang kurang berani menanggung resiko (risk averse), maka dengan nilai pertimbangan sebesar 3,57 termasuk katagori Medium, dengan kata lain bahwa Tobal Batik memiliki peluang bisnis yang cukup, meskipun secara relatif ancaman tetap ada namun peluang tumbuh tetap terbuka.

2) Penilaian variabel internal, diperoleh nilai tertimbang sebesar 3,28 , termasuk dalam katagori medium, artinya perusahaan memiliki keunggulan yang cukup dan masih dapat berkembang

3) Posisi Bisnis terletak pada sel yang terbentuk oleh niai medium kedua sumbu , terletak pada diagonal matrik, terletak pada sel "selektif " dengan kekuatan yang dimiliki maka bisnis perusahaan tersebut maka perusahaan tersebut memiliki peluang untuk berkembang.

4) Dengan analisi MDTI sangat membantu perusahaan dalam menentukan posisi bisnis masa yang akan datang.

\subsection{Saran}

Dari hasil kesimpulan analisi MDTItersebut maka saran kami :

a. Dalam menghadapi persaingan bisnis yang sangat kompetitif perusahaan harus berusaha memperhatikan varibale eksternal dan internal dengan perusahaan meminimalkan dan memperbaiki kelemahan yang ada, dengan meningkatkan potensi kekuatan yang dimilikinya

b. Agar kekuatan dan kelemahan dapat diketahui lebih terukur, perlu memanfaatkan analissi kekuatan dan kelemahan bisnis yang ada sisi eksternal dan sisi internal untuk melakukan pendekatan analisi MDTI.

\section{DAFTAR PUSTAKA}

Basu Swastha dan Irawan. 2000. Manajemen Pemasaran Modern. Liberty Yogyakarta:

Fandy Tjiptono. 2008. Strategi Pemasaran. Edisi III. Yogyakarta: Andi Offset.

Porter Michael E. 2000, Strategi bersaing , Teknik Menganalisa Industri Pesaing, Erlangga Jakarta

Kolter Philip : 2013, Manajemen Pemasaran Analisi, Perencanaan Implementasi dan Pengendalian, , Salemba Jakarta

R.A Supriyono : 2000 , Manajemen Strategi dan Kebijakan Bisnis Edisi I Yogyakarta: Andi Offset.

Sri Wayudi Agustinus : 2013, Manajemen Strategik, Pengantar Proses Berfikir , Bina Rupa Aksara , Jakarta

Suwarsono : 2013, Manajemen Startegi, Konsep dan Kasus , UPP AMP YKPN Yogyakarta 